\title{
Editorial
}

\section{A voz do povo é a voz de Deus........será?}

Antes que se faça alguma interpretaçáo ou leitura equivocada de minha opinião sobre a afirmação de Popper (Karl Raimund Popper, 1920-1996) que, com a retirada da indagação, acaba por ser o título do presente editorial, quero confessar que, apesar de tudo, ainda sou um democrata confesso. A expressão "apesar de tudo" é aqui usada para expressar a desilusão com um sistema que acabou abrigando em seu seio lideres como um Jörg Haider, na Áustria, um Jean Marie Le Pen, na França, e a penca de populistas que parecem florescer como nunca na América Latina. Todos "de um modo ou de outro" eleitos "democraticamente" e dirigentes da sociedade contemporânea.

Mas qual poderia ser a diferença entre os regimes e a sociedade do passado e a democracia supostamente sedimentada no presente. Haveria semelhanças entre ambas?

A concepção de sociedade na antiga Grécia encontrava na República (Platáo) a sua melhor definição e admitia o mito do destino que condenava essas sociedades a seguir por um caminho previamente traçado pelo visionário de plantão. Platáo acaba sendo o paladino desse tipo de sociedade ao defender, em seu modelo de Estado, um governo totalitário. A sociedade que defendia era utópica, esteticista e perfeccionista, identificada com um ideal social abstrato, não levando em conta a natureza do homem e a realidade material do mundo. Para Platáo, somente o iluminado pelas idéias poderia dirigir a sociedade para a sua perfeição. Ao povo, não iluminado pela idéia, a República, segundo palavras de Platão, "deverá ensiná-lo a não sonhar nunca, a não atuar com independência e a tornar-se incapaz de fazê-lo."

Esse tipo de sociedade foi denominada por Popper de sociedade fechada e foi defendida na contemporaneidade por Hegel e Marx. A concepçáo marxista da sociedade, dirigida exclusivamente pela economia, em permanente luta
Marco_Antonio Guimarães da Silva,Med.Dr.Sci.
marco@atlanticaedu.com.br

Marco Antonio Guimarães da Silva,Med.Dr.Sci.
marco@atlanticaedu.com.br

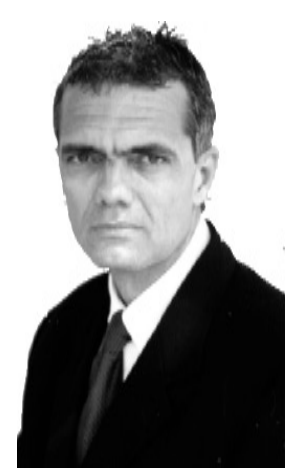

de classe, era formada por uma infra-estrutura material e superestrutura política e cultural, não deixando margem a nenhuma outra interpretação e a qualquer critica externa. Ou se estava com o Marxismo ou se estava contra ele. Para Popper a sociedade Marxista era utópica, messiânica e mal dirigida por umas profecias que prometiam uma igualdade perfeita. Tal qual a sociedade Platônica, a sociedade Marxista negava a liberdade aos que náo pertenciam ao grupo de profetas iluminados. A massa deveria seguir docilmente a seus lideres. As doutrinas defensoras deste tipo de sociedade pretendiam que a historia fosse dirigida por idéias ou metas finais e acabariam, segundo Popper, provocando um anquilosamento social. A solução para o problema, ainda segundo Popper, seriam a liberdade de todo mundo para opinar e contradizer os líderes políticos.

Ao que tudo indica, o Marxismo não mais é o fantasma que apavora a atual e "globalizada" (?) economia e a República parece não ser a bíblia da maioria dos dirigentes, até porque alguns deles teriam dificuldade em lê-la.

O limiar de pobreza, expresso em seus limites máximos em alguns paises da África e em quase todos os paises da América Latina, e a ingênua credulidade das grandes massas, presentes nessas regiōes e em paises da Europa e América do Norte, podem estar contribuindo para o surgimento dos populismos abertos ou velados, manejados pelos tiranetes de plantão, travestidos como democratas ou como republicanos. O resultado para tudo isso: a violaçáo das mais elementares normas da humanidade.

Lamentavelmente essa é a realidade do século XXI. E é uma lástima ter que constatar que o real e o ideal não andam de mãos dadas. O nosso ideal submetido a fatalidade modificável da história, acabou por adaptar-se a uma ditatorial e demagógica democracia. Platão nunca esteve tão atual!! 